\title{
PENGEMBANGAN PROGRAM OPAC (online public access catalogue) BERBASIS SUBJECT INDEXING UNTUK MEMPERMUDAH PENELUSURAN KOLEKSI JURNAL DI PERPUSTAKAAN UNIVERSITAS PENDIDIKAN GANESHA
}

\author{
N P Pramita Utami \\ UPT. Perpustakaan \\ Universitas Pendidikan Ganesha \\ Singaraja, Indonesia \\ email: pramitautami@yahoo.com
}

\begin{abstract}
Abstrak
Penelitian ini bertujuan untuk: : (1) Mengembangan program OPAC jurnal berbasis subject indexing untuk mempermudah penelusuran pada perpustakaan Undiksha, (2) Mengetahui kualitas program OPAC jurnal berbasis subject indexing berdasarkan hasil validasi, (3) Mengetahui efektiftas penggunaan program OPAC jurnal berbasis subject indexing pasca implementasi. Desain penelitian yang digunakan adalah penelitian pengembangan (Research and Development) dengan 100 sampel pemustaka yang dipilih melalui teknik accidental sampling. Program OPAC jurnal berbasis subjek indexing dirancang menggunakan aplikasi program Xampp, merupakan program katalog online yang otomatis dan informatif yang bertujuan untuk mempermudah penelusuran jurnal berdasarkan kata kunci atau subjek/topik yang diinginkan. Hasil validasi yang dilakukan menunjukkan bahwa dari segi keandalan (reliability), kebenaran (correctness), kemampuan menggunakan (useability), kemampuan memelihara (maintainability), kemampuan uji (testability), kemampuan interoperasi (interoperationalibility), keluwesan (flexibility), dan kepuasan menyeluruh (overall satisfaction) program sudah cukup baik. Program OPAC jurnal tersebut juga sudah cukup memuaskan dari segi isi dan tampilan muka. Hasil ujicoba juga menunjukkan bahwa program tersebut mampu untuk mempermudah penelusuran jurnal berdasarkan topik/subjek pembahasan yang diinginkan.
\end{abstract}

Kata-kata kunci: koleksi jurnal Undiksha, OPAC (online public access catalog), subject indexing

\begin{abstract}
The aims of the reserach were to (1) develop the journal OPAC program in the attempt to facilitate the journal searching, (2) know the quality of the journal OPAC program based on the result of validation, and (3) know the effectivity of the journal OPAC program in the attempt to facilitate the journal searching. This research used Research and Development design with 100 samples, which were selected through accidental sampling. The program developed is an automatic and informative online catalogue, which is aimed to facilitate the journal searching based on the key word or subject needed. The programmer uses Xampp aplication program in developing the program, which is considered easy in operating depended on the needed specification. The results of the validation show that in terms of reliability, correctness, useability, maintainability, testability, interoperationalibility, flexibility and overall satisfaction the program has shown good performance. The content and layout of the journal OPAC itself are also quite good. Besides, the results of try out also show that the program can facilitate the journal searching just in view second after typing the key word.
\end{abstract}

Keywords: journal collection of Undiksha, OPAC (online public access catalog),subject indexing 


\section{PENDAHULUAN}

Perpustakaan adalah inti dari setiap program pendidikan dan pengajaran atau dalam bahasa asingnya "the heart of educational program" (Soedibyo: 1987). Sebagai jantungnya pendidikan, perpustakaan Perguruan Tinggi berfungsi sebagai media pembelajaran yang berperan dalam menyediakan koleksi buku, audio visual juga menyediakan koleksi jurnal ilmiah yang berperan vital dalam menyokong kegiatan penelitian. Jurnal merupakan salah satu jenis koleksi perpustakaan yang memuat informasi penting untuk menunjang penelitian dan pembelajaran, (Djohan, 2010). Koleksi jurnal ilmiah baik dari luar negeri maupun domestik menjadi suatu kebanggaan perpustakaan. Singkatnya, koleksi jurnal ilmiah yang mutakhir dan berkualitas menjadi tolok ukur mutu referensi pembelajaran di Perguruan Tinggi. Hal ini bisa dilihat dari evaluasi pusat terhadap pemberian status terakreditasinya suatu Perguruan Tinggi, salah satunya adalah dari ketersediaan jurnal-jurnal ilmiah yang lengkap, up to date/terkini sekaligus terakreditasi.

Definisi jurnal dalam KBBI (2005) adalah majalah yang khusus memuat artikel dalam satu bidang ilmu tertentu. Kemudian dalam Encarta Dictionary (2008) mengungkapkan bahwa jurnal adalah majalah atau terbitan berseri, terutama yang diterbitkan oleh lembaga professional/ahli, yang memuat informasi dan kontribusi yang relevan dalam suatu bidang ilmu. Sebagai contoh, Jurnal Pendidikan dan Kebudayaan memuat kumpulan artikel ilmiah bidang pendidikan dan kebudayaan yang diterbitkan oleh Balitbang Kementrian Pendidikan Nasional. Jadi dalam satu jurnal terdapat beberapa tulisan dari para ahli yang umumnya merupakan hasil dari suatu penelitian yang tergabung dalam satu topik/subjek tertentu.

Berdasarkan definisi tersebut, dapat disimpulkan bahwa jurnal adalah majalah yang diterbitkan secara berkala oleh lembaga profesional yang memuat kajian ilmiah hasil penelitian dari para ahli yang terkumpul dalam suatu subjek ilmu.

Pentingnya keberadaan jurnal ilmiah tersebut bagi suatu lembaga pendidikan berimplikasi pada kebutuhan akan sistem pengelolaan jurnal yang tepat baik dari segi pengadaan/seleksi jurnal, pengolahannya maupun pelayanannya. Untuk itu diperlukan perhatian khusus pihak perpustakaan dalam pengorganisasian jurnal sehingga dapat didayaupayakan kepada pemustaka secara optimal.

Sementara di perpustakaan Undiksha, pengelolaan jurnal ilmiah belum terasa maksimal. Hal ini didukung oleh hasil penelitian Griadhi (2008) tentang pemanfaatan jurnal ilmiah di perpustakaan Undiksha, ditemukan bahwa pemanfaatan koleksi jurnal ilmiah menunjukkan jumlah yang minim, merujuk pada pengorganisasian jurnal yang belum optimal. Tim peneliti yang juga bertugas mengelola koleksi jurnal kurang lebih setahun lamanya mendapati kesulitan dalam memberikan pelayanan kepada pemustaka. Pemustaka umumnya datang mencari jurnal tanpa mengetahui nama jurnal maupun tahun terbit dan edisinya. Tentunya usaha pencarian kembali atau penelusuran jurnal menjadi tidak efektif dan efisien mengingat layanan koleksi jurnal hanya menyediakan katalog manual berbentuk buku yang memuat informasi urutan nama jurnal per fakultas, tahun terbit, edisi serta alamat terbitnya yang sudah disusun secara sistematis. Oleh karena itu, tim peneliti merasa kewalahan dalam membantu penelusuran kembali jurnal yang diinginkan pemustaka, mengingat pemustaka umumnya hanya memberi tahu subjek materi yang diperlukan.

Pemanfaatan koleksi jurnal ilmiah sebagai suatu bahan rujukan dalam penelitian maupun pendidikan adalah wajib bagi kaum akademisi pendidikan. 
Fenomena semacam ini terlihat pada penugasan dosen terhadap mahasiswa untuk mencari referensi jurnal ilmiah dalam menyelesaikan tugas perkuliahannya. Sebagian besar mahasiswa tersebut hanya mengetahui subjek-subjek tertentu sesuai topik tugas dari dosen bersangkutan tanpa mengetahui nama dan edisi jurnal. Pemustaka selain dari kalangan mahasiswa seperti para dosen, umumnya juga mencari referensi jurnal sesuai topik yang diinginkan dalam penyelesaian karya ilmiahnya. Hal ini pula mengakibatkan tim peneliti sebagai pengelola layanan jurnal serta terbitan berseri mengalami kesulitan dalam membantu penelusuran. Terkadang penelusuran tersebut membutuhkan waktu singkat bagi subjek-subjek terkini dan sering dicari, namun akan memerlukan waktu lebih lama bahkan dalam hitungan hari bagi subjek-subjek tertentu.

$\mathrm{Hal}$ tersebut berimplikasi pada rendahnya kepuasan pemustaka sebagai pengguna perpustakaan. Sebagaimana diketahui, perpustakaan adalah unit yang bergerak dibidang layanan, dimana pemustaka sebagai pelanggan adalah raja/pembeli informasi yang harus mendapatkan pelayanan yang memuaskan. Hal ini didukung oleh Milawati (2011), yang menyatakan bahwa pelayanan perpustakaan harus berorientasi pada kebutuhan pengguna, antisipasi perkembangan teknologi informasi dan pelayanan yang ramah, dengan kata lain menempatkan pengguna sebagai salah satu faktor penting dalam menentukan kebijakan pada suatu perpustakaan. Merujuk pada hal tersebut, maka pustakawan dituntut untuk meningkatkan profesionalitas layanan melalui sistem manajemen layanan yang cepat dan cermat.

Kenyataan akan tidak efektif dan efisiennya layanan yang sanggup diberikan oleh tim peneliti selaku pengelola jurnal menciptakan suatu renungan tersendiri bagi tim peneliti untuk memecahkan permasalahan tersebut. Beranjak dari sistem penelusuran manual dalam bentuk buku yang dirasa kurang efektif dalam pemberian layanan kepada pemustaka, maka tim peneliti tergerak untuk menggandeng keterlibatan teknologi informasi yang mampu mengatasi permasalahan tersebut dari segi kecepatan, ketepatan dan keakuratan subjek jurnal yang diperlukan. Hal ini sesuai dengan UU RI No 432007 tentang perpustakaan pada bagian ketiga mengenai pengelolaan dan pengembangan perpustakaan, khususnya pasal 19 ayat (2) yang berbunyi "Pengembangan perpustakaan sebagaimana dimaksud pada ayat (1) dilakukan berdasarkan karakteristik, fungsi dan tujuan, serta dilakukan sesuai kebutuhan pemustaka dan masyarakat dengan memanfaatkan teknologi informasi dan komunikasi".

Beranjak dari UU RI No 43 tersebut, tim peneliti ingin merancang penelusuran jurnal otomatis yang sering disebut dengan OPAC yaitu online public access catalogue (Arianto: 2006) berbasis subject indexing lengkap dengan tampilan abstraknya. Menurut Martono (1991), katalog adalah alat bantu untuk mempermudah penelusuran bahan pustaka. Perancangan katalog online/terpasang (Santoso: 2004) ini dikembangkan merujuk pada karakteristik permasalahan dalam penelusuran jurnal dengan tujuan agar pemustaka mendapatkan layanan yang memuaskan.

Penataan koleksi jurnal yang sistematis dalam hal ini disusun secara numerik per fakultas, per tahun dan per edisi serta dengan ketersediaan katalog online (OPAC) berbasis subject indexing diyakini tim peneliti mampu untuk dijadikan solusi yang revolusioner dalam sistem penelusuran jurnal.

Indeks dalam KBBI (2005), mempunyai arti kumpulan kata/istilah penting yang disusun secara alphabetis untuk memberikan informasi halaman kata/istilah itu ditemukan. Sedangkan, subjek dalam KBBI (2005) berarti pokok 
pembicaraan/pembahasan. Jadi dapat disimpulkan subjek indeksing adalah suatu process pengelompokan subjek yang tersusun secara sistematis.

OPAC dengan berbasis subject indexing dimaksudkan bahwa subjek atau topik pembahasan yang diperlukan oleh pemustaka menjadi acuan dasar pencarian dalam katalog online. Hal ini sesuai dengan fenomena pemustaka yang sering kali tidak mengetahui nama dan tahun jurnal yang dicari. Dengan demikian, pemustaka diharapkan mendapatkan kepuasan layanan tanpa harus mengobrak-abrik koleksi jurnal untuk mencari subjek yang diinginkan. Sedangkan, di pihak lain pemanfaatan jurnal sebagai bahan rujukan ilmiah juga optimal sehingga koleksi jurnal tidak hanya menjadi pajangan belaka.

Pengelaborasian sistem penelusuran OPAC pada jurnal berbasis subject indexing disinyalir menjadi solusi yang efektif dalam pengembangan layanan jurnal. Oleh sebab itu, komputerisasi perpustakaan/automasi perpustakaan sudah selayaknya untuk dikembangkan berdasarkan pada kemampuan dan kinerja yang diberikan oleh komputer itu sendiri. Pada dasarnya komputer dapat digunakan untuk mengawasi proses simpan dan temu kembali informasi; memelihara berkas informasi; mengatur dan mengatur ulang informasi. Corbin (1985:18) lebih menekankan keunggulan komputer sebagai berikut.

a. Mengerjakan volume pekerjaan yang berulang-ulang, hemat waktu, pelaksanaannya secara otomatis dan tepat dalam jangka waktu yang panjang.

b. Mengoperasikan dengan kecepatan tinggi, dapat diukur dalam satu per sejuta detik atau bahkan kurang.

c. Dapat mengerjakan sendiri sesuai dengan perintah yang sudah ditetapkan

d. Satu atau beberapa pekerjaan dapat dilaksanakan secara simultan.

e. Menerima informasi dan instruksi/perintah dari jarak jauh, memprosesnya dan mengirimkannya kembali kepada pemakainya.

Berdasarkan keunggulan teknologi komputer tersebut, maka dapat dijabarkan beberapa alasan terpilinnya solusi pengembangan program OPAC jurnal berbasis subject indexing sebagai berikut.

1. OPAC merupakan katalog on line yang mempunyai keunggulan dalam kecepatan dan keakuratan hasil penelusuran bahan pustaka.

2. Berbasis subject indexing bermanfaat bagi pemustaka dalam mempermudah pencarian jurnal walaupun tidak mengetahui nama jurnal yang dituju.

3. Tersedianya abstrak dalam OPAC jurnal berfungsi memberikan gambaran umum/ringkasan terhadap artikel yang dipilih berdasarkan subjek sebelum memutuskan mengambil dan membaca jurnal tersebut.

4. Pemustaka dapat melakukan penelusuran jurnal secara mandiri, hal ini sesuai dengan tujuan penyelenggaraan sistem perpustakaan terbuka (open access) dimana pemustaka diberikan kebebasan dalam memilih dan mengambil koleksi yang diinginkan, tidak perlu dibantu oleh petugas perpustakaan (Soedibyo: 1988).

5. Penambahan entri, yaitu catatan atau keterangan mengenai buku, nama orang serta badan hukum dalam daftar katalog atau OPAC (Soedibyo: 1987) dapat dilakukan dengan sangat mudah dan otomatis tanpa harus mecetak katalog baru.

6. Pustakawan, pengelola jurnal terbantu dalam penyimpanan kembali/shelving jurnal karena pemustaka tidak akan mengambil semua jurnal dalam rak.

7. Koleksi jurnal dapat berfungsi optimal bagi pemustaka yang membutuhkan bahan rujukan dalam penulisan karya ilmiah selain menjaganya dari kerusakan pemakaian yang tidak efisien. 
Mempertimbangkan fenomena tersebut diatas, dikembangkan program OPAC (online public access catalogue) berbasis subject indexing untuk mempermudah penelusuran jurnal di perpustakaan Undiksha. Hasil kajian ini diharapkan dapat membantu pihak perpustakaan dalam melakukan refleksi diri terhadap pengembangan perpustakaan di masa depan yang sarat akan informasi dan teknologi. Tujuan yang ingin dicapai dalam penelitian ini adalah untuk mengetahui: (1) Pengembangan program OPAC jurnal berbasis subject indexing untuk mempermudah penelusuran pada perpustakaan Undiksha, (2) Kualitas program OPAC jurnal berbasis subject indexing berdasarkan hasil validasi, (3) Efektiftas penggunaan program OPAC jurnal berbasis subject indexing pasca implementasi.

\section{METODE PENELITIAN Desain Penelitian}

Penelitian ini bertujuan untuk mengembangkan, memvalidasi dan mengujicoba program OPAC berbasis subject indexing, sehingga dalam penyusunan kajian ini penulis menggunakan desain penelitian pengembangan (research and development).

Dalam proses mempermudah penelusuran jurnal, ada dua indikator penting yaitu faktor otomatis dan penggunaan pendekatan subject indexing yang mendasari perlunya pengubahan sistem ke kondisi ideal yang diharapkan. Bertolak dari kedua aspek tersebut maka peneliti mendesain sebuah kajian pengembangan software/perangkat lunak yang mampu mempermudah penelusuran jurnal secara otomatis tanpa batasan ruang, waktu maupun tenaga.

\section{Populasi dan Sampel}

Seluruh pemustaka di perpustakaan Undiksha merupakan populasi penelitian. Rancangan pengambilan sampelnya menggunakan rancangan non-probabilitas (non-probability sampling) dengan teknik pengambilan sampel aksidental (accidental sampling). Menurut Faisal (2008), accidental sampling merupakan teknik pengambilan sampel "asal ambil atau asal pilih". Dalam hal ini, sampel terpilih merupakan pemustaka yang kebetulan menelusur/mencari informasi yang ada pada koleksi jurnal di perpustakaan Undiksha.

\section{Prosedur Penelitian}

Model prototyping dipilih dalam pengembangan software OPAC berbasis subject indexing. Prototyping merupakan metode standar dalam pengembangan software yang banyak digunakan para pengembang merujuk pada proses pembuatannya yang lebih interaktif. Dalam hal ini, peran antara pengembang dan pengguna dapat saling berinteraksi selama proses pembuatan sistem dengan tujuan untuk mencapai kebutuhan pengguna. Kerjasama yang baik akan memungkinkan pengembang dalam menganalisa kebutuhan pengguna dengan tidak mengesampingkan segi-segi teknis dalam mendesain software. Dengan demikian, program ini dapat diselesaikan sesuai dengan jadwal yang sudah ditentukan. Ada lima keunggulan model prototyping antara lain: (1) Adanya komunikasi yang baik antara pengembang dan pelanggan. (2) Pengembang dapat bekerja lebih baik dalam menentukan kebutuhan pelanggan. (3) Pelanggan berperan aktif dalam pengembangan sistem. (4) Lebih menghemat waktu dalam pengembangan sistem. (5) Penerapan menjadi lebih mudah karena pemakai mengetahui apa yang diharapkannya.

\section{Instrumen Penelitian}

Peneliti menggunakan tiga buah instrumen dalam pengumpulan data yaitu dengan kuesioner, pedoman observasi dan wawancara. Instrumen kuesioner/angket dan pedoman observasi digunakan untuk mengetahui tingkat kelancaran proses 
penelusuran jurnal. Metode pedoman observasi diterapkan dalam pengumpulan data, mempertimbangkan bahwa apa yang dikatakan seseorang sering kali berbeda dengan apa yang dilakukan, Bungin (2007). Dengan demikian, bias data dapat diminimalisir. Pedoman observasi dilakukan dengan pemantauan perilaku searching jurnal sebelum dan sesudah penerapan program OPAC berbasis subject indexing.

Angket merupakan alat pengumpulan data yang berisi kumpulan pernyataan tentang kajian yang akan diteliti yaitu program OPAC berbasis subject indexing yang memuat empat butir indikator seperti tergambar pada tabel 01 berikut.
Tabel 01 Kisi-kisi angket program OPAC berbasis subject indexing.

\begin{tabular}{|c|l|c|}
\hline NO. & INDIKATOR & $\begin{array}{c}\text { JUMLAH } \\
\text { ITEM }\end{array}$ \\
\hline 1. & Relevansi & 5 \\
\hline 2. & Efisiensi & 3 \\
\hline 3. & Keakuratan & 2 \\
\hline 4. & Kepuasan & 5 \\
\hline
\end{tabular}

Selanjutnya, wawancara tak berstruktur juga diterapkan dalam pengumpulan data. Teknik wawancara tak berstruktur diterapkan bertujuan untuk menggali informasi lebih lengkap dan akurat dari sisi responden. Data hasil wawancara kemudian merupakan data kualitatif. Berikut adalah tabel matriks pengumpulan data yang di desain dalam penelitian ini.

Tabel 02 Matriks Pengumpulan Data

\begin{tabular}{|l|l|l|l|l|}
\hline \multicolumn{1}{|c|}{ Instrumen } & \multicolumn{1}{c|}{ Sumber Data } & \multicolumn{1}{c|}{ Jenis Data } & Waktu Penerapan & Sifat Data \\
\hline Kuesioner & Pemustaka & $\begin{array}{l}\text { Respon pemustaka } \\
\text { terhadap program } \\
\text { OPAC. }\end{array}$ & $\begin{array}{l}\text { Pasca ujicoba } \\
\text { program }\end{array}$ & $\begin{array}{l}\text { Data } \\
\text { kuantitatif }\end{array}$ \\
\hline $\begin{array}{l}\text { Pedoman } \\
\text { observasi }\end{array}$ & $\begin{array}{l}\text { Perilaku } \\
\text { penelusuran } \\
\text { pemustaka }\end{array}$ & $\begin{array}{l}\text { Prosentase tingkat } \\
\text { kelancaran } \\
\text { penelusuran jurnal }\end{array}$ & $\begin{array}{l}\text { Pengambilan data } \\
\text { sebelum dan } \\
\text { sesudah ujicoba }\end{array}$ & $\begin{array}{l}\text { Data } \\
\text { kuantitatif }\end{array}$ \\
\hline $\begin{array}{l}\text { Wawancara } \\
\text { tak berstruktur }\end{array}$ & $\begin{array}{l}\text { Ahli program } \\
\text { komputer } \\
\text { Ahli bidang } \\
\text { kepustakawanan } \\
\text { Pemustaka }\end{array}$ & $\begin{array}{l}\text { Respon } \\
\text { programmer, } \\
\text { pustakawan yang } \\
\text { berkualifikasi, } \\
\text { pemustaka }\end{array}$ & $\begin{array}{l}\text { Validasi ahli dan } \\
\text { revisi }\end{array}$ & $\begin{array}{l}\text { Data } \\
\text { kualitatif }\end{array}$ \\
\hline
\end{tabular}

Berdasarkan tabel 02 diatas, dapat dijelaskan bahwa kuesioner diberikan kepada pemustaka yang telah menggunakan program OPAC dengan tujuan untuk mengetahui respon mereka terhadap program. Sedangkan, pedoman observasi diterapkan pada saat sebelum dan sesudah uji coba program, bertujuan untuk mengetahui prosentase tingkat kelancaran penelusuran. Dan, wawancara terhadap programmer, pustakawan serta pemustaka dilakukan untuk memvalidasi program.

\section{Analisis Data}

Merujuk pada dua model data yang dihasilkan (data kuantitatif dan kualitatif) maka ada dua teknik analisis data yang diterapkan. Analisis data kuantitatif dilakukan dengan pentabulasian data hasil kuesioner dan pedoman observasi pemantauan perilaku penelusuran. Selanjutnya diterapkan teknik analisis deskriptif dari hitungan data kuantitatif. Tahapan dalam analisis data kualitatif yaitu melalui (1) mentranskripsi data, (2) pengelompokan data dan (3) 
menginterpretasikan data menggunakan teknik deskriptif.

\section{Hasil dan Pembahasan}

\begin{abstract}
Program OPAC jurnal berbasis subject indexing merupakan program katalog online yang otomatis dan informatif yang bertujuan untuk mempermudah penelusuran jurnal berdasarkan kata kunci atau subjek/topik yang diinginkan. Dalam pengembangannya programmer menggunakan aplikasi program Xampp yang tergolong mudah dioperasikan dan disesuaikan dengan spesifikasi informasi yang diinginkan seperti data bibliografis jurnal, kode akses, cover jurnal dan tampilan abstrak jurnal.
\end{abstract}

\section{Validasi}

\section{Validasi Ahli}

Validasi ahli yang dilakukan
merupakan validasi kualitatif yang didapatkan melalui wawancara terhadap programer dan pustakawan. Hasil wawancara dengan programer menunjukkan bahwa program tersebut bisa dikatakan cukup memadai dan bermanfaat untuk kebutuhan perpustakaan. Programer menunjukkan bahwa dalam kaitannya dengan keandalan (reliability), kebenaran (correctness), kemampuan menggunakan (useability), kemampuan memelihara (maintainability), kemampuan uji (testability), kemampuan interoperasi (interoperationalibility), keluwesan (flexibility), dan kepuasan menyeluruh (overall satisfaction) program sudah cukup baik.

Program OPAC jurnal tersebut bisa menyelesaikan tugasnya dengan cukup akurat sesuai dengan tujuan pembuatannya yaitu untuk mempermudah penelusuran jurnal berdasarkan topik yang diinginkan. Program tersebut juga gampang dipelajari dan dipakai. Selain itu, programer secara umum menyatakan cukup puas dengan program tersebut.
Hasil wawancara dengan pustakawan juga menunjukkan hasil yang positif terkait dengan penyusunan program OPAC jurnal tersebut. Menurut pustakawan, penerapan teknologi dalam layanan penelusuran jurnal sangat tepat untuk diterapkan pada perpustakaan Undiksha. Hal ini merujuk pada paradigma perkembangan teknologi informasi yang mampu memberikan layanan secara efektif, efisien, dan akurat.

Mengenai aspek informasi yang tercantum dalam OPAC jurnal, pustakawan terwawancara menyatakan sudah cukup bagus dan menyarankan agar cantuman layanannya ditambah dengan menyediakan layanan interaktif jejaring sosial facebook atau email. Dengan demikian diharapkan pemustaka mendapatkan layanan yang optimal disesuaikan dengan kebutuhan dan minat pemustaka umumnya yang serba cepat, mudah dan digital tanpa batasan ruang maupun waktu.

Untuk mengetahui isi, keterbacaan dan efektivitas dari program OPAC jurnal ini bagi pemakai, maka peneliti juga melakukan validasi pemustaka. Validasi ini dilakukan dengan menyebarkan angket terhadap 100 pemustaka. Hasil angket ini kemudian ditindaklanjuti dengan proses wawancara.

Angket tersebut mengandung empat indikator penting seperti relevansi, efisiensi, keakuratan dan kepuasan pemakai. Hasil angket yang disebar ke pemustaka menunjukkan hasil yang juga sangat positif. $95,6 \%$ pemustaka setuju bahwa program OPAC jurnal tersebut memiliki relevansi dengan tujuan pembuatannya yaitu mempermudah pemustaka dalam penelusuran jurnal sesuai dengan topik/subjek yang diinginkan.95,7\% pemustaka mengungkapkan bahwa program OPAC jurnal tersebut efisien terkait dengan kemudahan/kecepatan dan dilengkapi tampilan cover dan abstrak. Sejalan dengan hal tersebut, maka waktu yang dibutuhkan oleh pemustaka dalam penelusuran tergolong singkat hanya 0,01 detik. $94 \%$ 
pemustaka setuju bahwa program OPAC jurnal tersebut akurat dalam penyajian data yang dicari dengan tampilan informasi bibliografis yang jelas. Selain itu, 95,3\% pemustaka juga menyatakan puas dengan tampilan OPAC jurnal, kemudahan akses dan layanan digital yang diberikan. Hasil wawancara mendukung temuan yang diperoleh melalui angket. Pemustaka tersebut menyatakan mendukung program OPAC jurnal berbasis subject indexing diterapkan di perpustakaan Undiksha merujuk pada perkembangan teknologi informasi di era globalisasi yang serba cepat, tepat dan efisien.

Responden mengungkapkan bahwa, keberadaan program OPAC jurnal ini sangat membantu mereka dalam penelusuran. Penelusuran dirasa sangat efektif hanya dengan mengetikkan kata kunci atau subjek yang dicari pada kolom pencarian/search maka program mampu menampilkan sejumlah abstrak dari satu atau beberapa buah jurnal. Gambaran umum tentang isi keseluruhan artikel diperoleh dari tampilan abstrak tersebut. Selanjutnya, dengan mengklik abstrak terpilih maka pemustaka akan mendapatkan kode akses lengkap dengan cover jurnalnya. Tampilan lengkap dari abstrak, kode akses, dan cover jurnal tersebut sangat disukai oleh pemustaka. Jadi hanya dalam hitungan menit, maka pemustaka sudah mendapatkan apa yang dicari.

Dukungan penuh dari pemustaka akan penerapan program OPAC jurnal sangat tinggi. Hal ini dapat dilihat dari respon pemustaka saat wawancara, menyatakan bahwa program OPAC jurnal ini sangat cocok diaplikasikan di perpustakaan Undiksha dalam rangka menyikapi perkembangan zaman yang serba digital. Untuk pengembangan perpustakaan kedepan, pemustaka yang umumnya adalah mahasiswa Undiksha berharap agar program OPAC jurnal ini terintegrasi dengan OPAC buku dan bisa diakses melalui internet. Pemustaka menginginkan program ini juga melayani pemesanan artikel jurnal untuk dicopy sehingga lebih praktis dan efisien waktu. Selain itu pemustaka juga menyarankan untuk mensosialisasikan keberadaan OPAC jurnal ini ke seluruh warga kampus Undiksha. Dan, melalui kajian ini pula pemustaka juga berharap adanya sinkronisasi antara dosen dengan pustakawan/perpustakaan dalam mengarahkan mahasiswa untuk lebih akrab dengan jurnal sebagai suatu referensi yang mutakhir.

\section{Hasil Ujicoba}

Observasi perilaku penelusuran koleksi jurnal dilakukan untuk mengetahui tingkat keefektifan pemustaka dalam mencari jurnal. Observasi dilakukan dengan membandingkan keefektifan penelusuran sebelum dan sesudah diberlakukannya program OPAC jurnal berbasis subject indexing. Hal ini dimaksudkan untuk membandingkan tingkat keefektifan/kemudahan penelusuran sehingga nantinya dapat diketahui efektivitas dari program tersebut.

Ujicoba program OPAC jurnal berbasis subject indexing dilaksanakan pada bulan September. Sedangkan, bulanbulan sebelumnya dijadikan sebagai pembanding sebelum diberlakukannya program.

\section{Observasi Penelusuran Sebelum Penerapan Program}

Perilaku pencarian jurnal oleh pemustaka sebelum penerapan program umumnya memerlukan waktu yang cukup lama bahkan mereka cenderung tidak bisa menemukan apa yang diinginkan. Tentunya kekecewaan yang melelahkan dirasakan oleh pemustaka. Pemustaka yang datang mencari jurnal umumnya tidak mengetahui data bibliografis jurnal seperti nama, volume, edisi, dan tahun terbit suatu jurnal yang tersedia dalam katalog manual. Pemustaka hanya datang dengan topik/subjek permasalahan. Hal inilah yang 
menyebabkan ketimpangan dalam penelusuran jurnal. Katalog manual yang tersedia tidak dapat berfungsi secara maksimal. Sebagai implikasinya, pemustaka menyisir setiap jurnal yang sudah dikelompokkan berdasarkan subjek umum seperti pendidikan dan pembelajaran masuk dalam kelompok jurnal FIP. Perilaku pencarian jurnal seperti ini berdampak pada hancurnya koleksi jurnal yang sudah ditata sedemikian rupa berdasarkan sistem numerik.

Susahnya penelusuran artikel yang terdapat dalam suatu jurnal tidak hanya

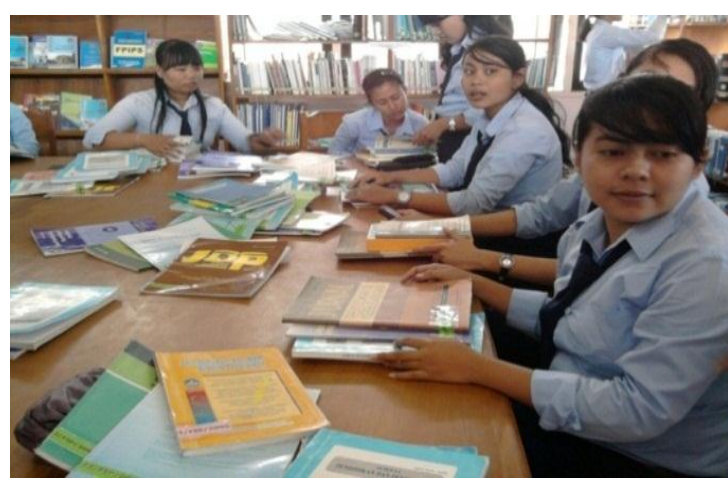

Gambar 01Penyisiran hampir sebagian besar koleksi jurnal kelompok FIP

Gambar 01 diatas menunjukkan bahwa penelusuran jurnal yang dilakukan secara konvensional sangat tidak efektif. Berdasarkan hasil observasi, rerata waktu yang dibutuhkan untuk mendapatkan jurnal yang memuat artikel yang dicari sebanyak 1 sampai 2 jam. Dan, penelusuran tersebut belum tentu membuahkan hasil yang diinginkan. Terkadang penelusuran tersebut dilanjutkan oleh pustakawan staff jurnal sebagai bentuk pesanan dari pemustaka untuk dicari keesokan harinya.

Pada gambar 02 diatas menunjukkan bahwa keadaan koleksi jurnal yang berantakan ditinjau dari tata letaknya pasca penelusuran jurnal. Sebagian besar koleksi jurnal dari kelompok FIP diturunkan dari rak selama penyisiran jurnal. Hal ini dirasakan oleh pemustaka. Pustakawan yang bertugas di bagian jurnalpun merasa kewalahan membantu penelusuran. Walau pustakawan staff jurnal yang setiap harinya berkutat dengan jurnal, namun tetap saja tidak bisa menghafal semua isi koleksi jurnal yang lumayan tidak sedikit.

Selain kewalahan dalam membantu penelusuran, pustakawan staff jurnal juga direpotkan dengan keadaan koleksi yang berantakan tata letak maupun fisiknya yang rusak. Berikut adalah gambar pemustaka yang menelusur koleksi jurnal sebelum diberlakukannya program OPAC.

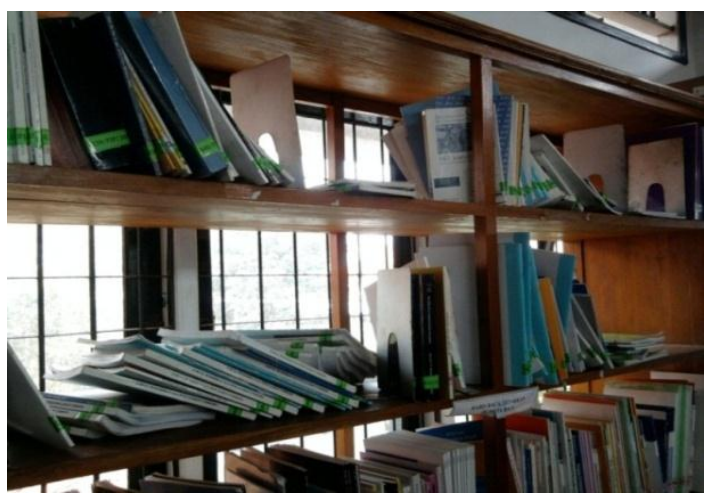

Gambar 02 Keadaan koleksi jurnal kelompok FIP pasca penyisiran jurnal

pula yang menyebabkan pustakawan staff jurnal merasa kewalahan untuk menatanya kembali berdasarkan kelompok subjek umum dan penomoran kode akses yang membutuhkan waktu yang cukup lama. Bisa dibayangkan dampak penelusuran jurnal yang sangat tidak efektif baik dari segi waktu dan tenaga untuk setiap harinya akan berdampak pada kerusakan fisik jurnal.

\section{Obsevasi Penelusuran Pasca Penerapan Program}

Ujicoba program OPAC jurnal berbasis subject indexing dilakukan pada bulan September. Berdasarkan hasil pengamatan, perilaku penelusuran jurnal berbanding terbalik dengan sebelum diterapkannya program. Rerata waktu yang 
dibutuhkan dalam menemukan jurnal yang memuat artikel yang dibutuhkan sebanyak 0,01 detik setelah pengetikan kata kunci/topik yang diinginkan.

Berikut adalah visualisasi tampilan program OPAC saat pemustaka melakukan penelusuran jurnal.

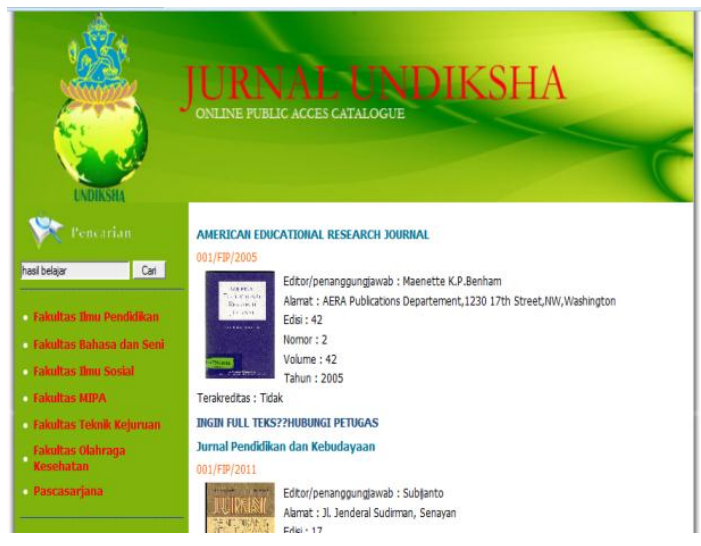

Gambar 03 Tampilan pemustaka mengetikkan kata kunci sesuai subjek yang diinginkan

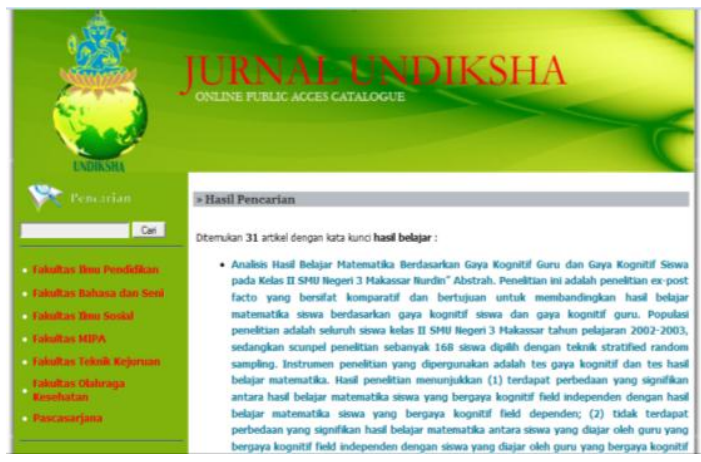

Gambar 04 Tampilan kumpulan abstrak sesuai kata kunci

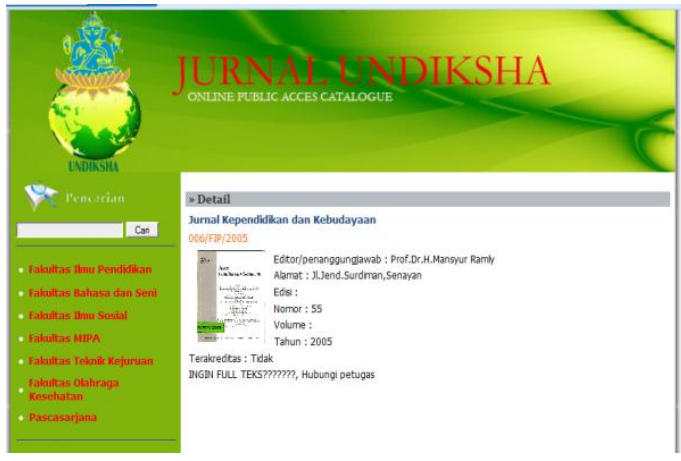

Gambar 05 Tampilan cover dan data bibliografis jurnal sesuai abstrak terpilih

Pemustaka yang mencari jurnal diarahkan untuk memakai fasilitas OPAC jurnal. Penelusuran yang ditawarkan sangat mudah dan cepat setelah mengetikkan kata kunci atau subjek/topik artikel yang diinginkan seperti terlihat pada gambar 03 . Dalam waktu yang sangat singkat pemustaka dapat memperoleh kumpulan abstrak artikel sesuai kata kunci yang diketik (gambar 04). Pemustaka kemudian browsing abstrak tersebut untuk dipilih sesuai minat yaitu dengan mengklik dua kali abstrak terpilih. Dengan demikian akan muncul tampilan deskripsi bibliografis jurnal lengkap dengan kode akses dan cover jurnal (gambar05). Hal ini dirancang oleh peneliti untuk memberikan gambaran umum yang jelas tentang jurnal yang dicari agar pencarian dalam rak koleksi bisa lebih efektif, mengingat koleksi jurnal sudah ditata berdasarkan urutan penomoran dan kelompok untuk setiap jurnal.

\section{Pembahasan}

Secara umum, program OPAC jurnal berbasis subject indexing sudah dapat dioperasikan pada layanan jurnal dan terbitan berseri. Peneliti berkolaborasi dengan programmer telah merancang program yang mudah dioperasikan dan memiliki kebermanfaatan tinggi.

Perancangan program tersebut diawali dengan menentukan spesifikasi 
program yang diinginkan menyangkut daftar bibliografis jurnal, kode akses, tampilan cover jurnal serta abstrak jurnal. Untuk itu, hal pertama yang dilakukan adalah memindai abstrak dan cover dari jurnal yang tergolong kelompok FIP sebagai sampel jurnal. Pemilihan sampel jurnal dari kelompok FIP ini dikarenakan oleh peminatnya yang banyak dan sering dicari. Setelah program siap untuk dipakai, maka data bibliografis jurnal, cover dan abstrak jurnal kemudian diinput ke program.

Proses revisi dan validasi program oleh tim ahli sudah dilakukan sebelum mengentri/memasukkan data jurnal. Validasi tersebut dilakukan oleh programmer dan juga oleh pihak pustakawan ahli yang berkualifikasi.

Program ini, bisa dikatakan cukup memadai dan bermanfaat untuk kebutuhan perpustakaan, seperti terbetik dari hasil validasi programer dan pustakawan. Hasil wawancara dengan programer menunjukkan hal tersebut dalam kaitannya dengan keandalan (reliability), kebenaran (correctness), kemampuan menggunakan (useability), kemampuan memelihara (maintainability), kemampuan uji (testability), kemampuan interoperasi (interoperationalibility), keluwesan (flexibility), dan kepuasan menyeluruh (overall satisfaction).

Program OPAC jurnal tersebut bisa menyelesaikan tugasnya dengan cukup akurat sesuai dengan tujuan pembuatannya yaitu untuk mempermudah penelusuran jurnal. Program tersebut juga gampang dipelajari dan dipakai. Selain itu, programer secara umum menyatakan cukup puas dengan program tersebut.

Hasil wawancara dengan pustakawan juga menunjukkan hasil yang positif terkait dengan penyusunan program OPAC jurnal tersebut. Menurut pustakawan, penerapan teknologi dalam layanan penelusuran jurnal sangat tepat untuk diterapkan pada perpustakaan Undiksha. $\mathrm{Hal}$ ini merujuk pada paradigma perkembangan teknologi informasi yang mampu memberikan layanan secara efektif, efisien, dan akurat.

Mengenai aspek informasi yang tercantum dalam OPAC jurnal, pustakawan terwawancara menyatakan sudah cukup bagus dan menyarankan agar cantuman layanannya ditambah dengan menyediakan layanan interaktif jejaring sosial facebook atau email. $\mathrm{Hal}$ ini diperuntukkan penyediaan layanan pemesanan jurnal untuk dicopy. Dengan demikian diharapkan pemustaka mendapatkan layanan yang optimal disesuaikan dengan kebutuhan dan minat pemustaka umumnya yang serba cepat, mudah dan digital tanpa batasan ruang maupun waktu.

Semua deskripsi tersebut terkait dengan program menunjukkan bahwa program OPAC jurnal yang dikembangkan sudah cukup baik walaupun masih harus dikembangkan dan disempurnakan. Program ini tergolong mudah dipakai, informatif dan memiliki kecepatan akses yang tinggi. Hal yang terpenting, program dapat melakukan apa yang diinginkan oleh peneliti dalam mempermudah penelusuran jurnal sehingga informasi yang dimiliki perpustakaan dapat tersampaikan kepada pemustaka yang memerlukan.

\section{Penutup}

Melalui kajian ini tersedia suatu program OPAC jurnal berbasis subject indexing yang informatif dan andal, serta memiliki kebermanfaatan yang tinggi dalam membantu pemustaka dalam menelusur informasi dalam jurnal dan juga pihak pustakawan dalam mengelola koleksi secara lebih efektif. Program ini memiliki beberapa keunggulan, selain tentu juga kelemahan, seperti mudah dioperasikan, mudah diakses, cepat, akurat dan lain-lain. Sehingga, disarankan bagi pihak perpustakaan atau yang tertarik untuk menerapkan dan jika mungkin memberikan umpan balik bagi kesempurnaan program yang telah disusun tersebut. 


\section{DAFTAR PUSTAKA}

Arianto, K.S. 2006. Aksentuasi perpustakaan dan Pustakawan. Jakarta: PD-IPI.

Bungin, B. 2007. Metodologi Penelitian Kualitatif. Jakarta: PT Raja Grafindo Persada.

Corbin, J. 1985. Managing the Library Automation Project. Canada: Oryx Press.

Djohan, H. 2010. Perancangan Arsitektur Perpustakaan Digital UPH dan relevansi Dspace sebagai Solusi Pengelolaan dan Penyebaran Grey Literature. Jurnal Pustakawan Indonesia. Vol.10,No.2(1).

Encarta Encyclopedia. 2008. Microsoft

Faisal, Sanapiah. 2008. Format-Format Penelitian Sosial. Jakarta: PT Rajagrafindo Persada

Corporation.

Griadhi, H.W. 2008. Pemanfaatan Koleksi Jurnal IImiah Luar Negeri pada Perpustakaan Universitas Pendidikan Ganesha. Laporan Penelitian DIPA yang tidak dipublikasikan. Lembaga Penelitian UNDIKSHA.

Kamus Besar Bahasa Indonesia edisi ke 3. 2005. Jakarta: Balai Pustaka.

Martono, E. 1991. Pengetahuan Dokumentasi dan Perpustakaan sebagai Pusat Informasi. Jakarta: Karya Utama.

Milawati. 2011. Improvement Strategies of Library Usages at the Public Libraries. Jurnal Berkala IImu Perpustakaan dan Informasi. Vol.7,No.2(14).

Santoso. 2004. Teknologi Informasi Perpustakaan:Bahan Ajar Diklat CPTA. Jakarta: Perpusnas RI

Soedibyo, N. 1987. Pengelolaan Perpustakaan (Jilid 1). Bandung: Penerbit Alumni.

Soedibyo, N. 1988. Pengelolaan Perpustakaan (Jilid 2). Bandung: Penerbit Alumni.

UU RI No 43 tahun 2007. Jakarta: Depdiknas

Webster's New World Dictionary. 1994. New York: Prentice Hall. 